Jan SANDNER

IEiB UKSW Warszawa

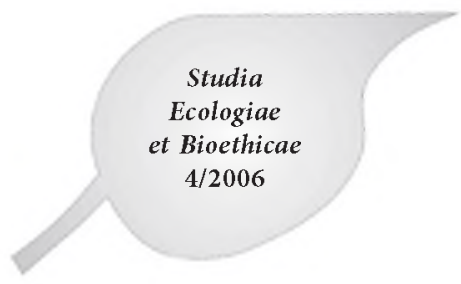

\title{
Environmental protection concept in holistic nature studies education
}

One of the environmental protection concepts is the concept of sustainable development. Sustainable development was first defined in the "Our Common Future" report under the auspices of the World Commission of Environment and Development by the United Nations and leadership of Mrs. Gro Brutland, the Prime Minister of Norway.

The act of formulating this concept was to have an impact on the people's attitude in relation to earth's environment resources. One cannot forget, that the shaping of the above concepts was taking place at a time when a large part of mankind was subject to various influences for which the common denominator, was by no means the ideology of respecting natural resources.

Man, during the span of the XX century, on a never been seen scale, succumbed to the old "you shall be like gods" temptation. The conviction about the perfection of man, of his self-sufficiency and autocreation created known mirages of godliness ensuing from the view, that God and religious values constitute an obstacle in the full development of man and primarily limit his freedom (Zdybicka 1988). From there, Promethean atheism, was born in the name of full appreciation of the value of man, "eradication of God" so that man could be: fully independent and mature (F. Nietzsche), absolutely free ( $\mathrm{S}$. Freud, J.P. Sartre), so he could attain heaven on earth, be his own salvation by revolutionary creation of new socio-economic structures (C. Marx, F. Engels, E. Bloch).

All of the above named philosophers and ideologists strove towards the elimination of God and religion from the life of man. They widely claimed, that God is only the creation of man, who hinders and limits man. Only when these types of limitations are lifted from man, he can then become free and capable of changing the face of the Earth. As transcendental God was eliminated, "new gods", new cults and religions were created in His place. One of the most dangerous of them to mankind became the myth of progress. It derives from the conviction, that science and based on it, technology will solve all human problems and create 
"heaven on earth". This consumptive attitude is the consequence of becoming fully convinced about the unlimited possibilities of science and technology.

All of these ideas landed on an exceptionally susceptible grounds during the second half of the XIX and first half of the XX centuries. Only now, do we see, how deceptive were these views. At the same time, it is only now that we are becoming aware of how dangerous man becomes when placed in place of God. Thus, we are for yet another time in history of mankind witnesses to man's awakening and shaking off the "being God" fascination. The former member countries of the Eastern block may serve to show just how dangerous was this process, leading so far as to the annihilation of entire nations. For it was in these countries, where man taking the place of God carried out the greatest devastation in human awareness and the environment. The attitude of the God people in the former USSR was responsible for the greatest ecological disasters, for the effects of which we shall continue to pay for decades and a great deal of them will probably will not be eliminated.

The progress myth is also not "foreign" to the "western" civilization. Naturally, this refers to progress taking place continuously, at the cost of resources of the natural environment. Degradation of the environment, which we are witnessing on a global scale resulting from the said actions, in its consequence, is no smaller then that of the previously mentioned so called "God people".

All of these, overlapping each other threats, for the first time became, at the beginning of the ' 80 of the passed century, a basis for formulating a new concept the primary objective of which became the protection of natural resources. What the creators of the sustainable development meant and drove at was such use of the resources so as to, by no means, limit and withhold ones needs but also consider the needs of others. In the final outcome, "sustainable development" was defined as a development that meets the needs of the present without compromising the ability of future generations to meet their own needs.

The creation of the "sustainable development" concept, most certainly became possible only along with the development of education studies on nature but primarily one of them, that which is the youngest, and that is ecology.

It is in Ecology that one should seek empirical sources for the creation of such concepts as, abiotic environment, biosphere, ecosystem, agrocoenosis, integration levels etc., which became the basis for formulating the concept of environmental protection and its resources. The "sustainable development" is, to a great degree, connected with the definition of ecology established as of 1869 introduced by Heackel - "Ecology is the management of nature".

Such understood environment became possible when it was finally fully understood what role is played by the so called uniform dormant environment of natural habitat later named biotope. Only the introduction of the biotope concept and connecting it with biocoenosis enable Tansley, in 1935 to formulate a new 
environment system which became the ecosystem. As biocoenosis and dormant environment function together, thus the system was named the ecosystem. Defining the ecosystem, its self-sufficiency level in the flow of matter and energy actually did become the breaking point in the so called holistic approach to the environment. Naturally, the ecosystem by itself was national a self-sufficient system as was the biosphere, nevertheless it could have successfully played the role of the basic unit in the research of environmental resources. The final definition of the concept of the ecosystem became one of the basic reference systems for the "sustainable development" concept.

The concept of "sustainable development" to the environmental resources is nothing other than management of the environment is such a manner so as to satiate ones own needs while simultaneously not permitting the so called depletion of its resources. From the time of the concept, the issue of its realization, in a certain sense remains open. From the very start we have here a great many quintessential problems. On one hand, these are all aspects pertaining to the definition of just the resources found in the environment as well as methods of analyzing their status. On the other hand we have the entire problematic issue of implementing the "sustainable development" concept. I am writing about the definition of environmental resources alone for a reason, as until recently not all resources were properly handled. To this day there exists the idea dividing resources into renewable and non-renewable. The consequences of this distinction pertaining to treating resources in such a manner are visible to this day. Fresh water resources or the so called ground resources suffered the most because the above said approach. Both in one as well as another case it has been understood and accepted that these are renewable resources, which may be managed "without limitations". Even greater mistakes were made in relation to underground water resources, forgetting about the fact, that it is them, which constitute the primary reserve of fresh water on land (over $30 \%$ of all resources).

The consequences of such a state of affairs are visible today worldwide. They didn't by-pass our continent either, including the most industrialized countries. It is in these countries, that the so called "progress myth" is responsible for an irreversible degradation of renewable resources. Each year we witness a series of erroneous decisions the result of which are annual floods in certain territories and on others, a progressing development of desert territories. Catastrophic floods tormenting Central-Eastern Europe in the summer of 2002 were the greatest floods since 1845. Climate change experts claim that this tendency will continue to increase together with global climate changes. How important this problem has become, even for the best developed countries we saw during the last Austrian presidency from January to June of 2006.

Austria pointed out new priorities, which it handled during the six month period it lead the European Commission, priorities such as: air contamination 
and precisely, the prevention against future floods. The primary priority for Austria is the flood prevention program as well as crisis management regulations as well as proposals for scientific research in this field.

From the research conducted within the "Desert Watch" program of the European Space Agency, thus far as many as 300 thousand sq. kilometers succumbed to land aridation already (that makes it an area larger than Great Britain) within the region of the Mediterranean Sea still populated by 16,5 million people. According to Jose Luise Rubio, the head of the aridation research center at the University in Valence the changing climate in Europe is directly tied with the progressing degradation of soil. New factors expediting the aridation process in Europe are, among others: changing climate, decrease of soil resistance to aridation, lowering of the level of ground waters, actions of man.

Aridation leads to an irrevocable process of the loss of great soil resources, which only theoretically is a renewable resource. Soil, or pedosphere constitutes the surface layer of the Earth's crust encompassed by soil-creative processes. As a basis element of lithosphere it is one of the most important elements of the land and water ecosystems. Soils are a part of the non-multiplying resources of the Earth glove and fulfill a series of functions, first of all as a habitat for the growth development of plants as well as transformation of mineral and organic elements. Soils thanks to specific to them attributes constitute a reflection of the history of landscape of which they are an essential part.

From the moment of formulating the concept of "sustainable development" increasing growing advancement in formulating leading tasks to be faced by the initiative can be seen. Nevertheless, as we see, it was actually the Austrian chairmanship, which began to introduce new elements of the environment constituting another type of danger. In light of this direction of thought it is more clearly visible what loopholes we have in our evaluation or to say it in other words, in monitoring environmental resources. The said loopholes are the result of not only a very diversified technological background but also the education level.

Again, it turns out that the factor which is capable of truly stopping the process of the sustainable development is the educational process itself. The hitherto teaching methods about the environment do not withstand against the needs of the societies opened to the dangers of ever new challenges. The environmental education problem practically pertains to all teaching levels. And it is not just our country's problem. It is a problem which to a lesser or greater degree practically touches all countries. If we want to fix the environment, protect its resources and what is most important, understand its mechanisms, then new models should be created as fast as possible or teaching all subjects about nature. A good quintessential examples, which should help us to understand the principles on which the new system should be bases may be the life organization 
levels concept. Some of them in organizational order are: biocoenosis, ecosystem, population, organism, organ, cell and gene. At each of these levels characteristic systems were created where exchange of matter and energy takes place. Ecology, to defines its scope of interest, also used the life organization levels concept. Ecology is the study of life organization levels of the above body.

In constructing a new system about the study of the natural environment, we should use the integration levels concept known from ecology. This relates to the fact, that the properties of given levels separated from the whole are not possible to be foreseen. For that reason, for example research should be conducted both on the forest (that is, the whole) as well as the trees (that is, its parts). One cannot foresee the properties of water only knowing the properties of hydrogen and oxygen, one cannot foresee the properties of the ecosystems based on the knowledge of qualities of isolated populations.

In general, it may be said, that the more comprehensive the tested systems there appear still more comprehensive and complex in their system ecological structures. Our problem with education about the environment within nature studies is bases precisely on that, that we focused on researching and understanding processes making up the so called parts. In this process, we almost completely forgot about the so called whole. In ecological research method, however, this was not forgotten. There are two basic ecological research methods. One was named by Forbes as mereological from the Greek word Meros - part and the other by Birge as holistic from the Greek word Holos - whole.

The first of these methods successfully developed together with the technological progress and research possibilities of the environment. It was difficult to explain the complex hypotheses without collecting appropriate "luggage" of knowledge about nature or the true structure of the world.

For that reason the holistic approach became possible only at the moment when already there was an appropriate amount of observation of nature's reality available. Based on that the development theory was introduced by J.Ch. Smuts, propagated by some English biologists and philosophers at the beginning of the XX century. The said theory referred to the most important problem of essence pertaining to the proper interpretation of the reality of nature. It claimed, that the whole cannot be brought down to the sum of parts or elements and the world is subject to evolution, during which new wholes continue to emerge. This theory became the basis for understanding one of the most important processes in ecology and environmental protection and that is, the so called synergy.

Plant and animal organisms develop under the constant pressure of ecological factors. One can study the impact of each of the said factors under laboratory experimental conditions. Under natural conditions, it is very difficult as they act together and the effect of the said action, as a rule is different from the sum of the impact of individual factors separately. That is the phenomena called synergy. 
Based on the example of synergy taking place in the environment (overlapping processes, which we not only want to learn about but also, up to a point, to control), it is probably easy to see in which direction should be geared changes in the construction of natural environment education programs. Firstly, the said changes, should pertain to the university departments where subjects on nature are taught. Subjects, which essentially decide about the knowledge of the nature's environment by future graduates. The following subjects pertain to the above: Ecology, Hydrology, Water Management, Dynamic Geology, Geomorphology, Soil Knowledge, Geology of Resources, Forestry, Meteorology, Toxicology etc. The hitherto teaching system, under no circumstances, guarantees, learning by the students of environmental mechanisms deciding about the actual condition and quality of the environment. The resources of knowledge from the above listed subjects are, most frequently taught using a mereological method with all the consequences thereof.

Quintessential knowledge in the scope of basic subjects on nature should also be adapted to the EU programs and directives based on which the natural environment management process is being conducted. Here, I have in mind such programs as: the sustainable development concept, or the Framework Water Directive of the European Union.

At the Cardinal Stefan Wyszyński University's Institute of Ecology and Bioethics (at Environmental Protection major) within the realization of the said concept an attempt was made of holistic approach toward the natural studies education problem. The following subjects from the listed scientific disciplines take part in this program: Ecology, Hydrology and Water Management, Dynamic Geology, Geomorphology and Soil Knowledge.

\section{Bibliography}

P.A. ALLEN, Procesy ksztattujace powierzchnię Ziemi, PWN, Warszawa 2000, s. 474.

Botkin Daniel, Keller Edward, Environmental Science, John Wiley \& Sons INC, New York 1995, s.625.

Chełmicki W, Woda, zasoby, degradacja, ochrona, PWN, Warszawa 2001, s. 301.

Książkiewicz M., Geologia dynamiczna, Wyd. Geol., Warszawa 1979, s. 776.

Krebs CH., J., Ekologia, Eksperymentalna analiza rozmieszczenia i liczebności, PWN Warszawa 1996, s. 730 .

Sandner J., Badania postaw proekologicznych spoleczeństwa polskiego, Świadomośc i edukacja ekologiczna, Wydawnictwo ATK, Warszawa 1998, s. 37-53.

Sandner J., The Problems of Environmental Education in Agribusiness, w: Studia Ecologiae et Bioethicae, t.3, Wydawnictwo UKSW, Warszawa 2006.

Sandner J., Czlowiek a środowisko przyrodnicze; Konflikty spoleczno-ekologiczne, Edukacja ekologiczna chrześcijaństwo, wydawnictwo Verbinum, Warszawa 2003. 
Skowroński A., Idea zrównoważonego rozwoju w polskiej polityce ekologicznej, w: „Studia Ecologiae et Bioethicae"1:653-681 Wydawnictwo UKSW, Warszawa 2003.

Smuts, J.C. Holism and Evolution, Macmillan Co., New York 1926.

Zdybicka Z.J., Religia i religioznawstwo, Redakcja Wydawnictw KUL, Lublin 1998, s. 447.

\section{STRESZCZENIE}

Artykuł jest próbą analizy procesu edukacji proekologicznej w świetle problematyki ochrony środowiska w UE na tle idei, reprezentowanych, przez takich filozofów i ekologów, jak: Forbes, Smuts, Tansley, Haeckel, Birge. Autor przedstawia ciekawy wywód prowadzący do zgoła innego spojrzenia na problematykę środowiska przyrodniczego. W swoim wywodzie podpiera się znanymi teoriami z pogranicza ekologii i filozofii, takimi jak: teoria rozwoju, poziomów integracji, czy synergizm. Autor porusza trudną problematykę z pogranicza różnych nauk, związaną $\mathrm{z}$ poznawaniem środowiska. Główną ideą autora jest podjęcie próby holistycznego podejścia do problemu edukacji przyrodniczej. Podejście to ma gwarantować lepsze rozumienie środowiska, poprzez uruchomienie nowej jakości w jego zarządzaniu i rozwiązywaniu narastających sytuacji kryzysowych w środowisku. 